\title{
Elm and maple processing rates : comparisons between and within streams
}

\author{
S.B. Gazzera1 \\ K.W. Cummins ${ }^{2}$ \\ G. Salmoiraghi ${ }^{3}$
}

Keywords : Streams, allochthonous detritus, leaf processing, shredder functional group.

Leaf breakdown rates of two species of elm (Ulmus) and two of maple (Acer) were investigated in two low order streams located in Western Maryland, U.S.A., and in Northern Appenins, Italy. Within each genus of leaf, one species was Italian and one was American. The role of macroinvertebrate shredders in leaf processing was also investigated. In both streams within the same genus of leaf the Italian leaves disappeared faster than the American leaves. Within the same species, the leaves were decomposed more rapidly in the Italian stream. Shredder biomass was always significantly higher on the leaves retrieved from the Italian stream suggesting that shredders had an important role in detritus processing. On the contrary, the comparison between leaf species showed a poor correlation between shredder biomass and leaf breakdown rate. Three hypotheses are proposed. The fact that native leaves were not processed at a faster rate, compared to the exotic leaves, support the notion that shredders do not specialize on litter of a given leaf species, but rather on appropriately conditioned leaf litter regardless of the species. Breakdown rates followed the same rank ordering in each stream : Acer pseudoplatanus > Ulmus minor $>$ Ulmus americana $>$ Acer rubrum indicating the existence of the same hierarchy in the availability of food to macroinvertebrates throughout the year.

\section{Taux de décomposition des feuilles d'orme et d'érable : comparaisons entre et à l'intérieur des torrents}

Mots-clés : Torrents, détritus allochtones, décomposition des feuilles, déchiqueteurs.

Les taux de décomposition de deux espèces d'orme (Ulmus) et de deux espèces d'érable (Acer) ont été étudiés dans deux torrents d'ordre 1 et 2 situés dans l'Ouest Maryland, U.S.A. et dans le Nord des Apennins, Italie.

Pour chaque genre de feuille, une espèce était italienne et l'autre américaine.

Le rôle des macroinvertébrés déchiqueteurs sur la décomposition des feuilles a été également étudié. Dans les 2 rivières, pour le même genre, les feuilles italiennes disparaissent plus vite que les américaines. Pour la même espèce, les feuilles étaient plus rapidement décomposées dans la rivière italienne. La biomasse des déchiqueteurs était toujours significativement plus élevée sur les feuilles extraites de la rivière italienne suggérant que les déchiqueteurs jouent un rôle important dans la décompositions. Au contraire, la comparaison entre les espèces dé feuille a montré une faible corrélation entre la biomasse des déchiqueteurs et le taux de décomposition foliaire.

Trois hypothèses sont proposées. Le fait que les feuilles indigènes n'étaient pas décomposées plus rapidement que les exotiques conforte l'idée que les décomposeurs ne se spécialisent pas sur une espèce particulière de feuille, mais qu'ils sont plutôt tributaires du préconditionnement convenable de la litière, indépendamment de l'espèce de feuilles qui la compose.

Les taux de décomposition suivent le même ordre dans chaque rivière : Acer pseudoplatanus $>$ Ulmus minor $>$ Ulmus americana $>$ Acer rubrum ce qui indique l'existence de la même hiérarchie dans la nourriture disponible pour les macroinvertébrés pendant l'année.

1. Biology Department, Virginia Commonwealth University, Richmond, VA 23284, U.S.A.

2. University of Pittsburgh, 350 Thackeray Hall, Pittsburgh, PA 15260 , U.S.A.

3. Dipartimento di Biologia Evoluzionistica Sperimentale, Via S. Giacomo 9, Bologna, Italy. 


\section{Introduction}

Low oder streams draining deciduous forests are highly dependent on allochthonous detritus as an energy source which is represented mainly by leaves and needles (CPOM), (Minshall 1967, Fisher \& Likens 1973, Cummins 1974, Boling et al. 1975, Vannote et al. 1980). After leaching of soluble compounds, leaves and needles are colonized by fungi and bacteria, then by macroinvertebrates. The physical and chemical changes brought about microorganisms (conditioning), make detritus more palatable for macroinvertebrates (e.i. Kaushik \& Hynes 1971, Petersen \& Cummins 1974, Suberkropp \& Klug 1976, Findlay \& Arsuffi 1989). Shredders are the macroinvertebrates that feed directly on leaf tissue and the role they play in breaking down allochthonous organic matter is well established (e.i. Cummins 1973, 1974, Short et al. 1980, Wallace et al. 1982, Cummins \& Wilzbach 1985).

Chemical characteristics of plant tissue can significantly affect the rate to which detritus is decomposed (Kaushik \& Hynes 1971, Petersen \& Cummins 1974). Petersen \& Cummins (1974), classify allochthonous detritus in fast $(k>0.01$ day -1$)$, medium $(\mathrm{k}=0.005-0.01$ day -1$)$, and slow $(k>0.005$ day -1 ) categories, depending on the breakdown rate. The existence, within a riparian vegetation system, of leaves decomposing at different rates has a remarkable ecological importance, translating into a hierarchy in decomposition rates, and thus availability of food to macroinvertebrates throughout the year following the major autumn inputs (Petersen \& Cummins 1974, Cummins et al. 1989). Water temperature and chemical characteristics are important factors in determining decomposition rates as well (Hynes \& Kaushik 1969, Carpenter \& Adams 1979, Meyer \& Johnson 1983, Hanson et al. 1984, Brock et al. 1985).

In recent years, several studies have focused on estimating processing rates for a large number of leaf species (e.g. see review by Webster \& Benfield 1986). But to date, little information exists comparing detritus processing rates in streams draining different geographical areas (Minshall et al. 1983, Gazzera et al. 1991). Latitudinal regions that have similar climates tend to have similar types of lotic systems. Nevertheless, there can be differences in abiotic and biotic aspects such as geomorphology, topography, chemistry and floral and faunal commu- nities. The strong linkage existing between streâms and their terrestrial surroundings is well established (Vannote et al. 1980) and life-cycle, density, and biomass of stream macroinvertebrates are influenced by these variables (Vannote et al. 1980, Cushing et al. 1983, Minshall et al. 1985). For instance growth rate and life cycle of some macroinvertebrates seem to be affected by food abundance (Cummins \& Klug 1979 ) as well as food quality (Anderson \& Cummins 1978, Ward \& Cummins 1978).

The purpose of the present study was to compare processing rates of leaves placed in streams located in two different geographic areas having similar latitude, climate, and stream order. The study sites were in Western Maryland, U.S.A., and in Northern Appennins, Italy. We chose four species of leaves belonging to elm (Ulmus) and maple (Acer) genera. Within each genus, one species was Italian (Ulmus minor (L.) and Acer pseudoplatanus (L.) and one was North American (Ulmus americana (L.) and Acer rubrum (L.)). In particular, we focused on comparing : 1) processing rates of leaves belonging to the same species placed in the two streams ; 2) and processing rates of leaves belonging to the same genus placed in the same stream. All four species were studied in each stream two were native and two exotic. In both comparisons, the role of macroinvertebrate shredders in leaf processing was investigated. According to the literature, elm species decompose at a fast rate $(k>0.01$ day -1$)$ and maple species at a medium rate $(\mathrm{k}=0.005-0.01$ day-1), (Petersen \& Cummins 1974, Webster \& Benfield 1986, Cummins et al. 1989).

\section{Study sites}

Piney Run is a second order, low gradient, woodland, brook trout stream located within the Youghiogheny River basin of the Ohio River drainage system in Garrett County, Maryland (Wilzbach \& Cummins 1989). The substrate in composed mainly of sand and during our experiment the $\mathrm{pH}$ varied from 6.0 to 8.5 and the alkalinity from 30 to $40 \mathrm{mg} / \mathrm{l}$ $\mathrm{CaCO}_{3}$. Nitrate and total phosphorus were in the range of $500 \mu \mathrm{g} / \mathrm{l}$ and $30-40 \mu \mathrm{g} / 1$ respectively. Mean temperature was $12.8^{\circ} \mathrm{C}$. Riparian vegetation along the study reach of Piney Run is dominated by Acer rubrum (L.), Betula allaghanensis (Britton), (yellow birch), Tsuga canadensis (L.), (hemlock) and Rhododentron maximum (L.), (rhododentron) (Cummins 
mins et al. 1989). Young Ulmus americana occurred sparsely in the watershed.

Brasimone Creek is a first order, medium gradient stream located in the Appennins in the central part of Italy (region Emilia-Romagna). The sediment is dominated by pebbles and cobbles. During the course of our study, the mean $\mathrm{pH}$ was 7.5 and the mean alkalinity was $70 \mathrm{mg} / \mathrm{lCaCO}_{3}$. Nitrate ranged from 60 to $330 \mu \mathrm{g} / 1$ and total phosphorus from 5 to $60 \mu \mathrm{g} / 1$. Mean temperature was $14.0^{\circ} \mathrm{C}$. Fagus silvatica (L.), (European beech), Ulmus minor and Acer pseudoplatanus (L.) are characteristic riparian species.

\section{Material and methods}

We used the leaf-pack technique described by Petersen \& Cummins (1974) and Merritt et al. (1979). The leaves were collected just before abscission and air dried. During the summer of 1988 (JulyAugust in Brasimone Creek ; August-September in Piney Run) at least twenty $5 \mathrm{~g}( \pm 0.1)$ leaf-packs of each species were placed in each stream. The iming of leaf-pack collection was based on tempeature accumulation as degree-days read, on average of twice per week, on maximum-minimum thermoneters. Because of the difference in processing rates Jetween the two genera, elm leaves were collected it 150,300 , and 450 degree-days, and maple leaves :very 225,450 , and 675 degree-days. Initial samples vere collected after 24-48 hour incubation in the itreams in order to determine pack weight loss due o leaching of soluble compounds. Initial leaching $s$ essentially independent of microbial and macroinrertebrate activity and water temperature and itrongly dependent upon leaf physical and chemi;al characteristics (Kaushik \& Hynes 1971, Peterien \& Cummins 1974) and discharge (Petersen 1984).

Five leaf-packs were randomly collected on each iampling occasion. The packs were taken to the aboratory, rinsed to remove extraneous material und separate macroinvertebrates, dried at $50^{\circ} \mathrm{C}$ for 18 hours, and reweighed.

Decay coefficients were calculated from a negaive exponential model (Olson 1963, Petersen \& Zummins 1974). This model includes days, as the inly independent variable, and initial weight (after eaching) as the dependent variable. In order to evauate temperature effects, the two independent variale model proposed by Hanson et al. (1984) was also applied and tested for significance $(P<0.05)$. This model adds temperature, expressed in degree-days, to the previous model as a second variable. Covariance analysis $(\mathrm{P}<0.05)$ was used to compare leaf processing rates (Snedecor \& Cochran 1978).

Macroinvertebrates were identified to genera (subfamilies and tribes in Chironomidae) in most cases, measured, and assigned to functional feeding groups (Merritt \& Cummins 1984). Organism biomass was computed from length-weight regressions (The INVERTCALC, Cummins and Wilzbach, Univ. of Pittsburgh ; Rogers et al. 1977, Smock 1980). The non parametric Mann-Whitney U-test $(\alpha=0.05$; Sokal \& Roholf 1981) was used to compare shredder functional group density and biomass between dates, leaf species and streams.

The last elm leaf-packs were retrieved after 35 and 32 days in Piney Run and Brasimone Creek respectively, and maple leaf-packs after 56 days and 48 days in the two streams respectively.

\section{Results}

The decomposition rates after leaching $(\mathrm{k})$ from the single variable model are given in table 1 .

Table 1. Breakdown rates, confidence intervals, and correlation coefficients (** $P<0.01)$ for the four leaf species in each stream.

Tableau 1. Taux de décomposition, intervalles de confiance et coefficients de corrélations ( ${ }^{* *} P<0,01$ ) pour les quatre espèces de feuilles dans chaque torrent.

\begin{tabular}{lccc}
\hline Piney Run & & & \\
& $\mathrm{k}$ & $95 \%$ C.I. & $\mathrm{r}$ \\
$U$. minor & 0.026 & $0.023-0.034$ & $0.887^{* *}$ \\
U. americana & 0.013 & $0.010-0.016$ & $0.805^{* *}$ \\
A. pseudoplatanus & 0.029 & $0.024-0.032$ & $0.888^{* *}$ \\
A. rubrus & 0.014 & $0.013-0.017$ & $0.898^{* *}$ \\
Brasimone Creek & & & \\
$U$. minor & 0.036 & $0.029-0.044$ & $0.809^{* *}$ \\
U. americana & 0.030 & $0.025-0.035$ & $0.881^{* *}$ \\
A. pseudoplatanus & 0.054 & $0.044-0.064$ & $0.850^{* *}$ \\
A. rubrum & 0.015 & $0.012-0.018$ & $0.792^{* *}$ \\
\hline
\end{tabular}

In two of the eight cases, Acer rubrum in Piney Run and in Brasimone Creek, the addition of temperature to the model was statistically significant. Temperature normalized processing rates were 0.013 day -1 and 0.014 day -1 in Piney Run and Brasimone Creek respectively. The breakdoxn rates from the two independant variable model are given in Table 2. 
Table 2. Breakdown rates normalized for temperature for the four leaf species in each stream.

Tableau 2. Taux de décomposition (normalisés pour la température) calculés pour les quatre espèces de feuilles dans chaque rivière.

\begin{tabular}{lc}
\hline Piney Run & $\mathrm{k}$ \\
& 0.026 \\
U. minor & 0.013 \\
U. americana & 0.029 \\
A. pseudoplatanus & 0.013 \\
A. rubrus & \\
Brasimone Creek & 0.036 \\
U. minor & 0.030 \\
U. americana & 0.054 \\
A. pseudoplatanus & 0.014 \\
A. rubrum & \\
\hline
\end{tabular}

Comparison of processing rates within the same genus (Fig. 1) showed that in both streams the leaf species of Italian origin (Ulmus minor and Acer pseudoplatanus) were decomposed faster than the North American species (Ulmus americana and Acer rubrum). Covariance analysis (Table 3 ) indicated that all comparisons but elm in Brasimone Creek were statistically significantly different. Within the same species (Fig. 2), the leaves disappeared faster in the Italian stream than in Piney Run. Again covariance analysis was applied and the comparisons statistically significant were those of Ulmus americana and Acer pseudoplatanus. Acer pseudoplatanus in Brasimone Creek disappeared at the fastest rate $(\mathrm{k}$ $=0.54$ day -1 ) and Acer rubrum and Ulmus americana in Piney Run had the slowest rates $(\mathrm{k}=0.013$ day -1$)$.

Table 3. Probabilities associated with covariance analysis of linear regressions of beakdown rates for the same leaf species between countries, and between species in the same country (* $P<0.05)$.

Tableau 3. Probabilités obtenues par l'analyse de covariance de régressions linéaire pour le taux de décomposition de la même espèce de feuille selon le pays et entre espèces dans le même pays $(* \mathrm{P}<0,05)$.

\begin{tabular}{lccc}
\hline SPECIES & $\begin{array}{c}\text { SAME SPECIES } \\
\text { BETWEEN } \\
\text { COUNTRIES }\end{array}$ & \multicolumn{2}{c}{$\begin{array}{c}\text { SAME COUNTRY } \\
\text { BETWEEN } \\
\text { SPECIES }\end{array}$} \\
\hline $\begin{array}{l}\text { ELM } \\
\text { Italian }\end{array}$ & $0.14 \mathrm{NS}$ & Italy & U.S. \\
$\begin{array}{l}\text { American } \\
\text { NAPLE } \\
\text { Italian }\end{array}$ & $0.00 *$ & $0.17 \mathrm{NS}$ & $0.00^{*}$ \\
American & $0.00 *$ & & \\
\hline
\end{tabular}

In Brasimone Creek the leaves were colonizec mainly by shredders and, at lower density, by col lectors. The highest biomass values were calculatec for the shredders with the exception of $A$. rubrun with higher collector biomass (Fig. 3). Baetis spp. and Protoneumura spp. were the most abundan taxa apart from the Chironomidae (Orthocladiinae Tanypodinae, Tanytarsini, and Chironomini). Pre dators were found among Diptera, and a few scra. pers and gathering collectors among the Coleopter: and Plecoptera. Hydroptilidae (Trichoptera) was thi only representative of the piercer functional grour (Merritt \& Cummins 1984).

In Piney Run the main summer colonizers wer filtering and gathering collectors (Tanypodinae Tanytarsini, Orthocladiinae, and Paraleptophlebic spp.). The few shredder individuals found were pri marily Hydratophylax argus (Harris), Pychnopsy. che scabripenni (Rambur) and Lepidostoma spp. The highest biomass values were calculated for the collectors followed by the shredders (Fig. 4). Fev scrapers were present (in the Ephemeroptera anc Coleoptera) and predators were represented prima rily by tipulids and athericids and virtually no pier ces were found.

Generally, in both streams, the same taxa colo nized all four leaf species and all functional group: were represented.

Total macroinvertebrate biomass (Table 4) anc density, as a ratio of percent leaf remaining, was hig her for the leaves of Italian origin in both Brasimon Creek and in Piney Run (for instance, in Piney Run total macroinvertebrate biomass was $0.20,0.25$ anc 0.42 on $U$. minor and $0.03,0.08$, and 0.17 on $U$ americana respectively at 150,300 , and 450 degree days). Within the same leaf species, higher biomas and density were observed on the leaves collectec from the Italian stream (total macroinvertebrate bio mass on $A$. pseudoplatanus was $0.43,0.28$, and 5.0 in Brasimone Creek and $0.30,0.16$, and 0.81 ir Piney Run respectively at 225,450 , and 675 degree days).

In Brasimone Creek, both the Italian lea species (elm and maple) had higher shredder den sity than the American leaves on all sampling dates with the exception of elm at the 150 degree-day when more shredders colonized Ulmus americana Silarly, in Piney Run, higher shredder densitie were associated with the Italian species of leaves 

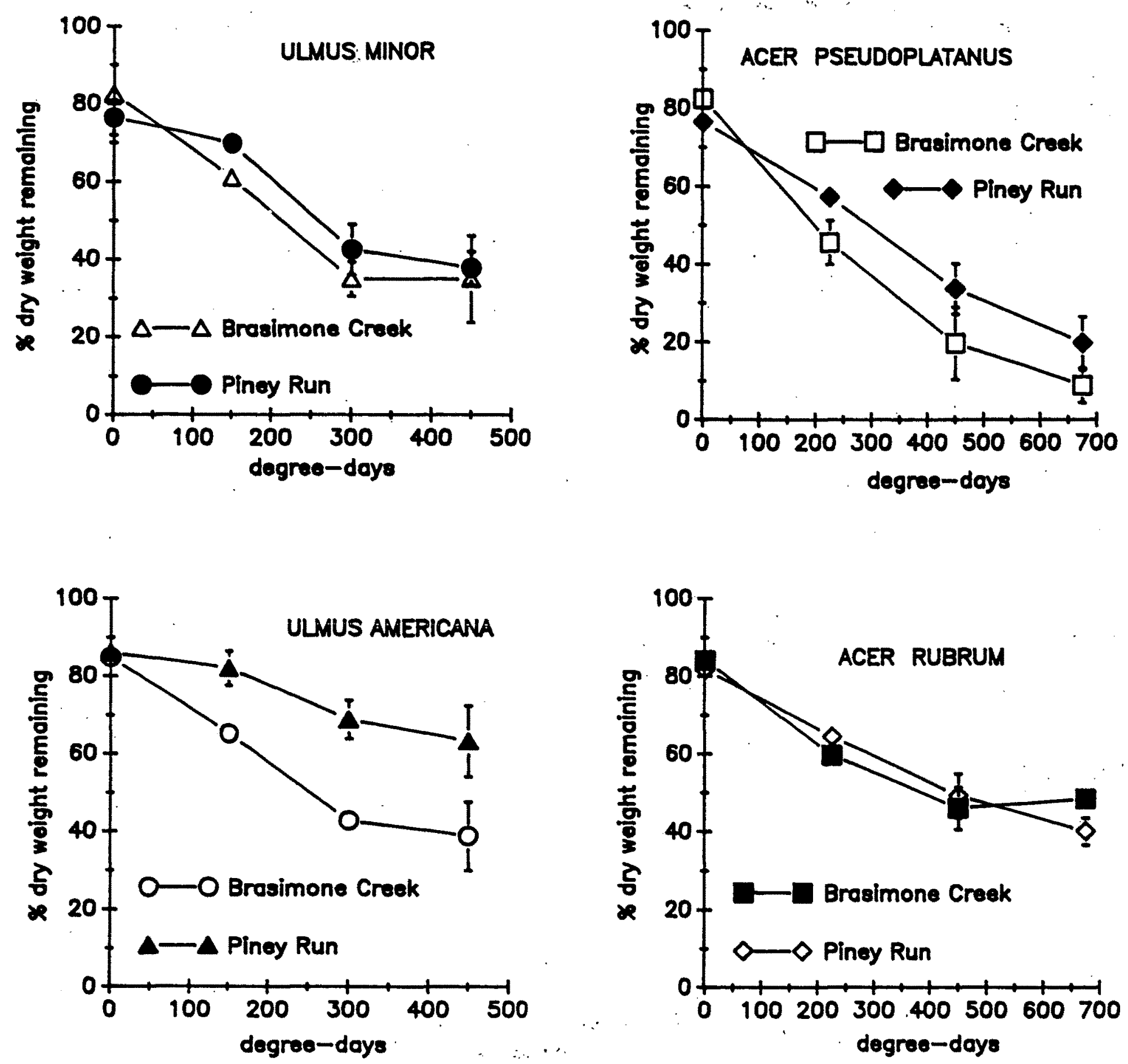

Fig. 2. Percent of initial dry weight remaining versus degree-days (error bars represent standard deviation). Comparisons within thi same species.

Fig. 2. Pourcentage de poids sec initiäl restant en fonction du nombre de degré-jours. Comparaisons pour une même espèce selon le torrent

Two exceptions, out of six cases, occurred : at the 150 degree-day sampling interval for elm and at the 450 degree-day sampling interval for maple. Comparing shredder density within the same leaf species, more individuals colonized the elm and maple leaves placed in Brasimone Creek.

Shredder biomass, as a ratio of percent leaf mass remaining, had a pattern similar to density. In the
Italian stream, Brasimone Creek, shredder biomas: was always higher on the native leaf species at each sampling interval (Fig. 5). In the American stream. Piney Run, a higher biomass was calculated for the shredders found on the exotic elm except at the 150 degree-day interval, and higher biomass occurred or the Italian maple at the first sampling interval only. Within the same species of leaf, shredder biomass 


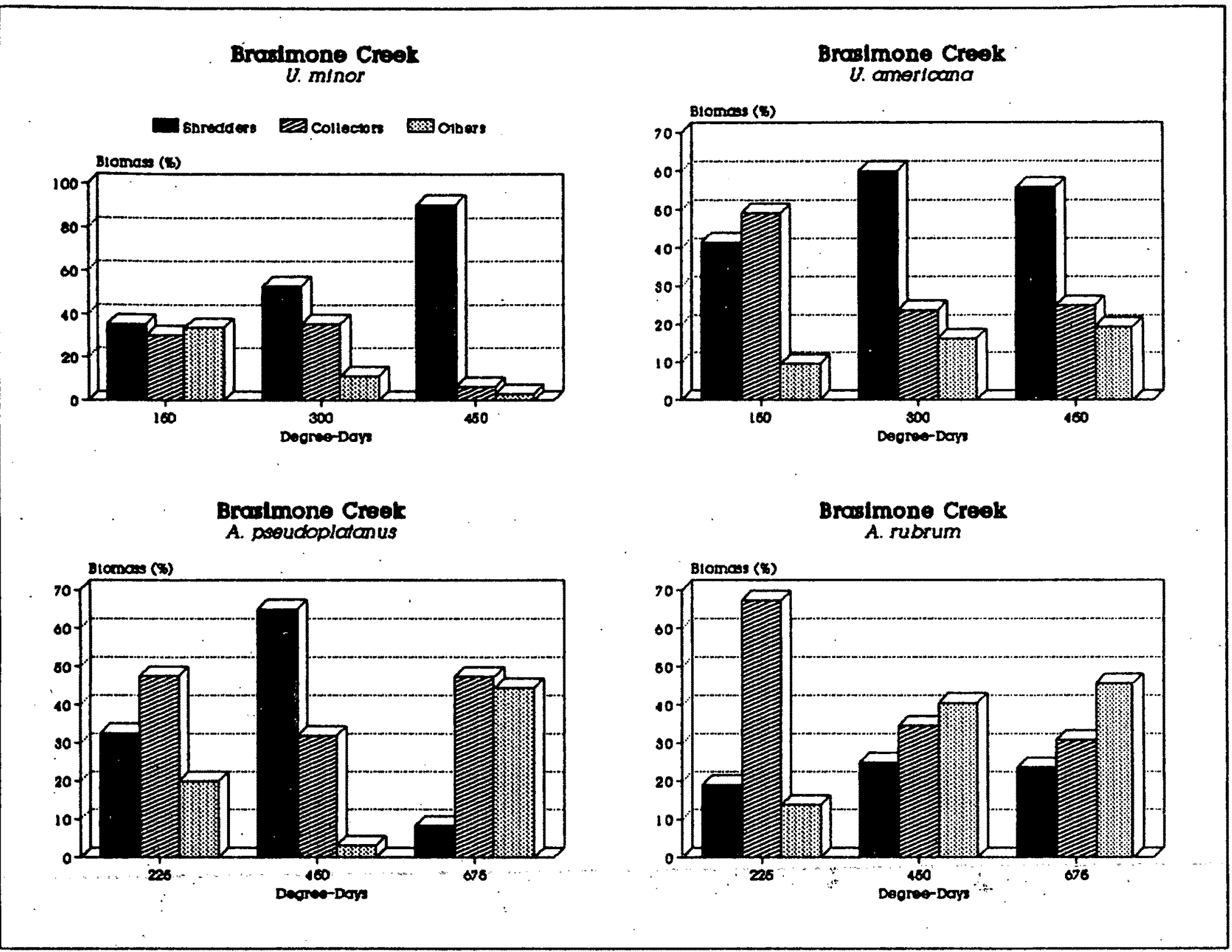

Fig. 3. Biomass percent composition of functional groups colonizing the leaf-packs placed in Brasimone Creek.

Fig. 3. Pourcentage de la biomasse des différents groupes fonctionnels colonisant les paquets de feuilles placés dans Brasimore Creek.

was always higher on the leaves retrieved from Brasimone Creek (Fig. 6). This pattern occurred for all species on all sampling occasions, except for $A$. rubrum at 675 degree-days when higher shredder biomass was associated with the leaves retrieved from Piney Run.

Comparing shredder density within the same genus of leaves in Brasimone Creek the only comparison that was statistically significant (MannWhitney U-test) was for the maple leaves at the 675 degree-day interval (Table 5). In Piney Run, the test was always significant for maple, but never for elm. Comparison within the same leaf species showed that shredder density was significantly higher on the leaves retrieved from Brasimone Creek for all four leaf species at all four sampling occasions.

With respect to shredder biomass, the comparison within the same leaf genus was never significantly different (Mann-Withney U-test) for the leaves retrieved from Piney Run (Table 6). In the Italian stream, shredder biomass was significantly higher only on the Italian maple at the las sampling interval.

Within the same leaf species, the test was significant for the first and second sampling interval of both Ulmus minor and Acer pseudoplatanus. The test was always significant for Ulmus americana, and at the 450 degree-day interval for Acer rubrum. 
Table 5. Probabilites associated with Mann-Withney test on shredder density within genus (above), and within (below) species of leaf $(\mathrm{P}<0.05)$

Tableau 5. Probabilities obtenues avec le test de Mann-Withney appliqué à la densité des décomposeurs pour un même genre (au-dessus), et pour chaque espèce (au-dessous) de feuilles $(\mathrm{P}<0,05)$.

Brasimone Creek

Ulmus spp.

$150 \mathrm{~d}-\mathrm{d}$

$300 \mathrm{~d}-\mathrm{d}$

$450 \mathrm{~d}-\mathrm{d}$

Piney Run

Ulmus spp.

$150 \mathrm{~d}-\mathrm{d}$

$300 \mathrm{~d}-\mathrm{d}$

$450 \mathrm{~d}-\mathrm{d}$

$$
\begin{aligned}
& p=0.20 \\
& p=0.10 \\
& p=0.50
\end{aligned}
$$

Acer spp.

225 d-d

$450 \mathrm{~d}-\mathrm{d}$

$675 \mathrm{~d}-\mathrm{d}$

$\mathrm{p}=\mathbf{0 . 3 5}$

$\mathrm{p}=0.10$

$\mathrm{p}=0.05$

Acer spp.

$225 \mathrm{~d}-\mathrm{d}$

$\mathrm{p}=0.50$

$\mathrm{p}=0.10$

$\mathrm{p}=0.35$

$675 \mathrm{~d}-\mathrm{d}$

$p=0.05$
$p=0.05$
$p=0.05$

Brasimone Creek

Ulmus minor

$150 \mathrm{~d}-\mathrm{d}$

$300 \mathrm{~d}-\mathrm{d}$

$450 \mathrm{~d}-\mathrm{d}$

Piney Run

Ulmus americana

$150 \mathrm{~d}-\mathrm{d}$

$300 \mathrm{~d}-\mathrm{d}$

$450 \mathrm{~d}-\mathrm{d}$ $\mathrm{p}=0.05$
$\mathrm{p}=0.05$

$\mathrm{p}=0.05$
$\mathrm{p}=0.05$

$\mathrm{p}=0.05$

$\mathrm{p}=0.05$

$\mathrm{p}=0.05$
Acer pseudoplatanus

$225 \mathrm{~d}$-d- $\quad \mathrm{p}=0.05$

450 d-d-

$\mathrm{p}=0.05$

$675 \mathrm{~d}$-d-

$\mathrm{p}=0.05$

\section{Acer rubrum}

$225 \mathrm{~d}-\mathrm{d}$

$450 \mathrm{~d}-\mathrm{d}$

$\mathrm{p}=0.05$

$675 \mathrm{~d}-\mathrm{d}$

$\mathrm{p}=0.05$

$\mathrm{p}=0.05$

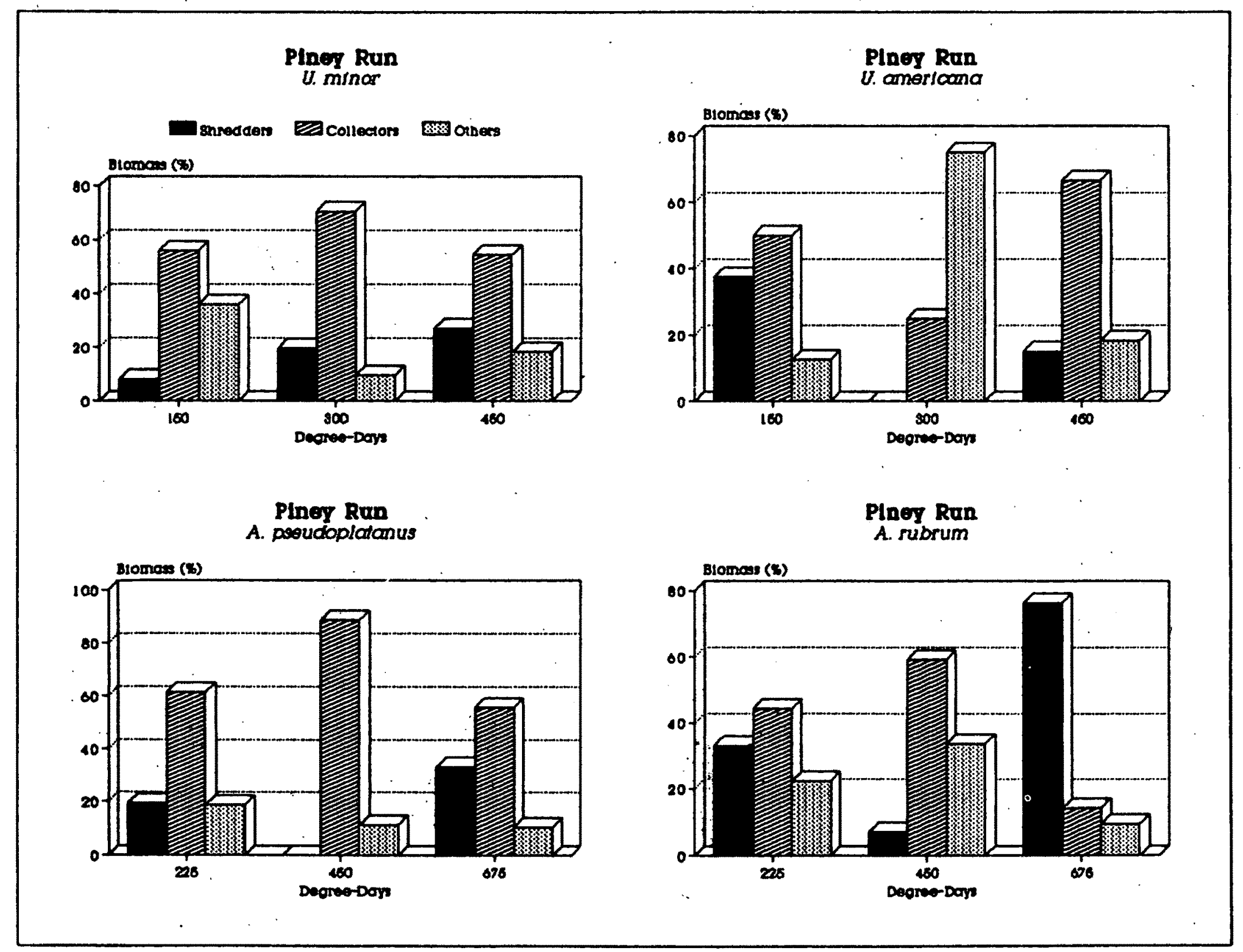

Fig. 4. Biomass percent composition of functional groups colonizing the leaf-packs placed in Piney Run.

Fig. 4. Pourcentage de la biomasse des différents groupes fonctionnels colonisant les paquets de feuilles placés dans Piney Run. 
Table 6. Probabilites associated with Mann-Withney test applied on shredder biomass within genus (above), and within (below) species of leaf $(P<0.05)$.

Tableau 6. Probabilités obtenues avec le test de Mann-Withney appliqué à la biomasse des décomposeurs pour un même genre (audessus), et pour chaque espèce (au-dessous) de feuilles $(P<0,05)$.

Brasimone Creek

Ulmus spp.

$150 \mathrm{~d}-\mathrm{d}$

$300 \mathrm{~d}-\mathrm{d}$

450.d-d

Piney Run

Ulmus spp.

$150 \mathrm{~d}-\mathrm{d}$

$300 \mathrm{~d}-\mathrm{d}$

$450 \mathrm{~d}-\mathrm{d}$

$\begin{array}{lll}\mathrm{p}=0.50 & \begin{array}{l}\text { Acer spp. } \\ \text { 225 d-d }\end{array} & \mathrm{p}=0.20 \\ \mathrm{p}=0.10 & 450 \mathrm{~d}-\mathrm{d} & \mathrm{p}=0.10 \\ \mathrm{p}=0.50 & 675 \mathrm{~d}-\mathrm{d} & \mathrm{p}=0.05 \\ & & \\ & \text { Acer spp. } & \\ \mathrm{p}=0.50 & 225 \mathrm{~d}-\mathrm{d} & \mathrm{p}=0.20 \\ \mathrm{p}=0.10 & 450 \mathrm{~d}-\mathrm{d} & \mathrm{p}=0.10 \\ \mathrm{p}=0.50 & 675 \mathrm{~d}-\mathrm{d} & \mathrm{p}=0.35\end{array}$

\begin{tabular}{|c|c|c|c|}
\hline \multicolumn{4}{|c|}{ Brasimone Creek } \\
\hline $150 \mathrm{~d}-\mathrm{d}$ & $p=0.05$ & 225 d-d- & $p=0.05$ \\
\hline $300 \mathrm{~d}-\mathrm{d}$ & $\mathrm{p}=0.05$ & $450 \mathrm{~d}-\mathrm{d}-$ & $\mathrm{p}=0.05$ \\
\hline $450 \mathrm{~d}-\mathrm{d}$ & $\mathrm{p}=0.20$ & $675 \mathrm{~d}-\mathrm{d}-$ & $\mathrm{p}=0.35$ \\
\hline \multicolumn{4}{|c|}{ Piney Run } \\
\hline Ulmus al & & Acer rub & \\
\hline $150 \mathrm{~d}-\mathrm{d}$ & $p=0.05$ & $225 \mathrm{~d}-\mathrm{d}$ & $p=0.10$ \\
\hline$d-d$ & $\mathrm{p}=0.05$ & $450 \mathrm{~d}-\mathrm{d}$ & $\mathrm{p}=0.05$ \\
\hline $450 \mathrm{~d}-\mathrm{d}$ & $p=0.05$ & $675 \mathrm{~d}-\mathrm{d}$ & $p=0.35$ \\
\hline
\end{tabular}
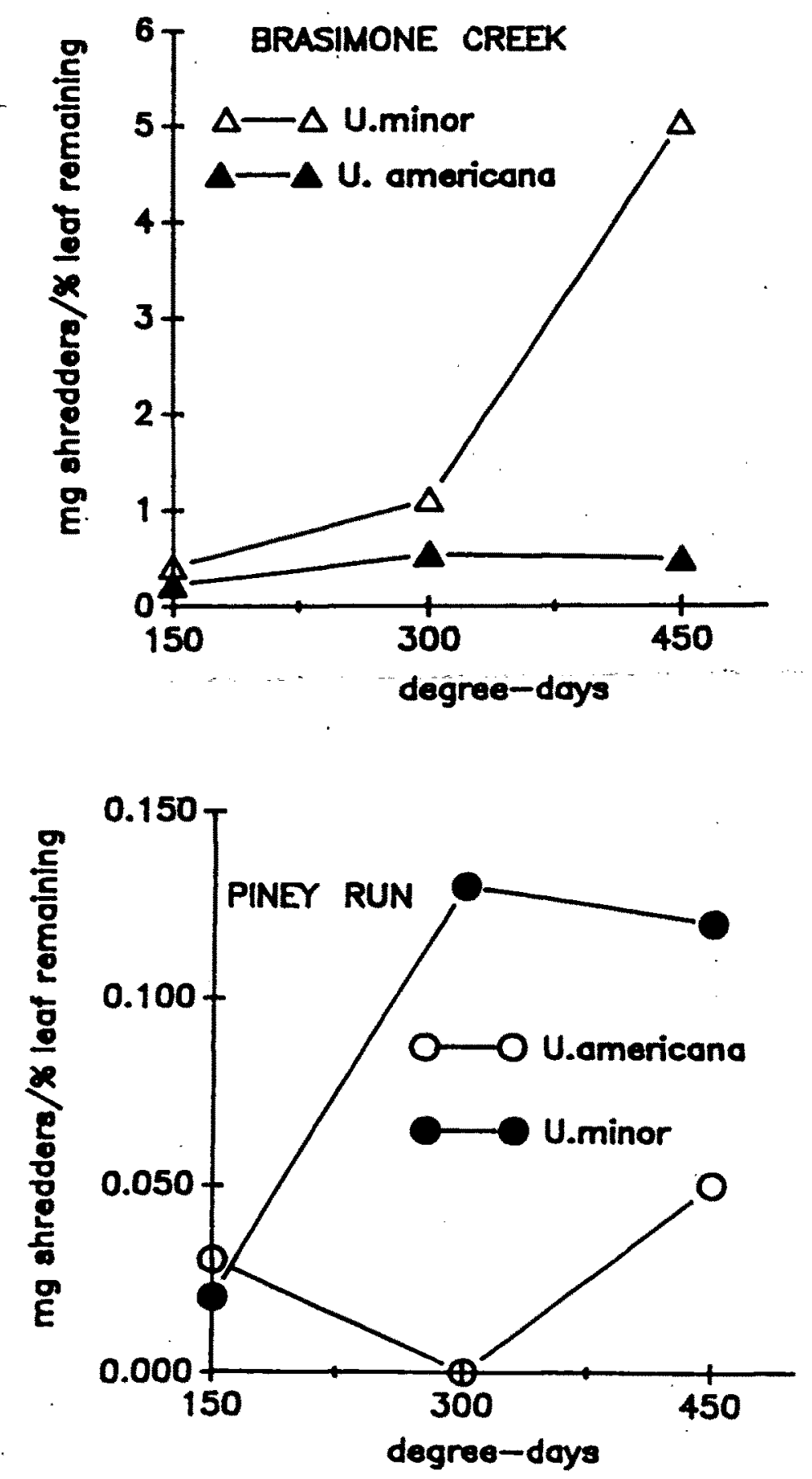
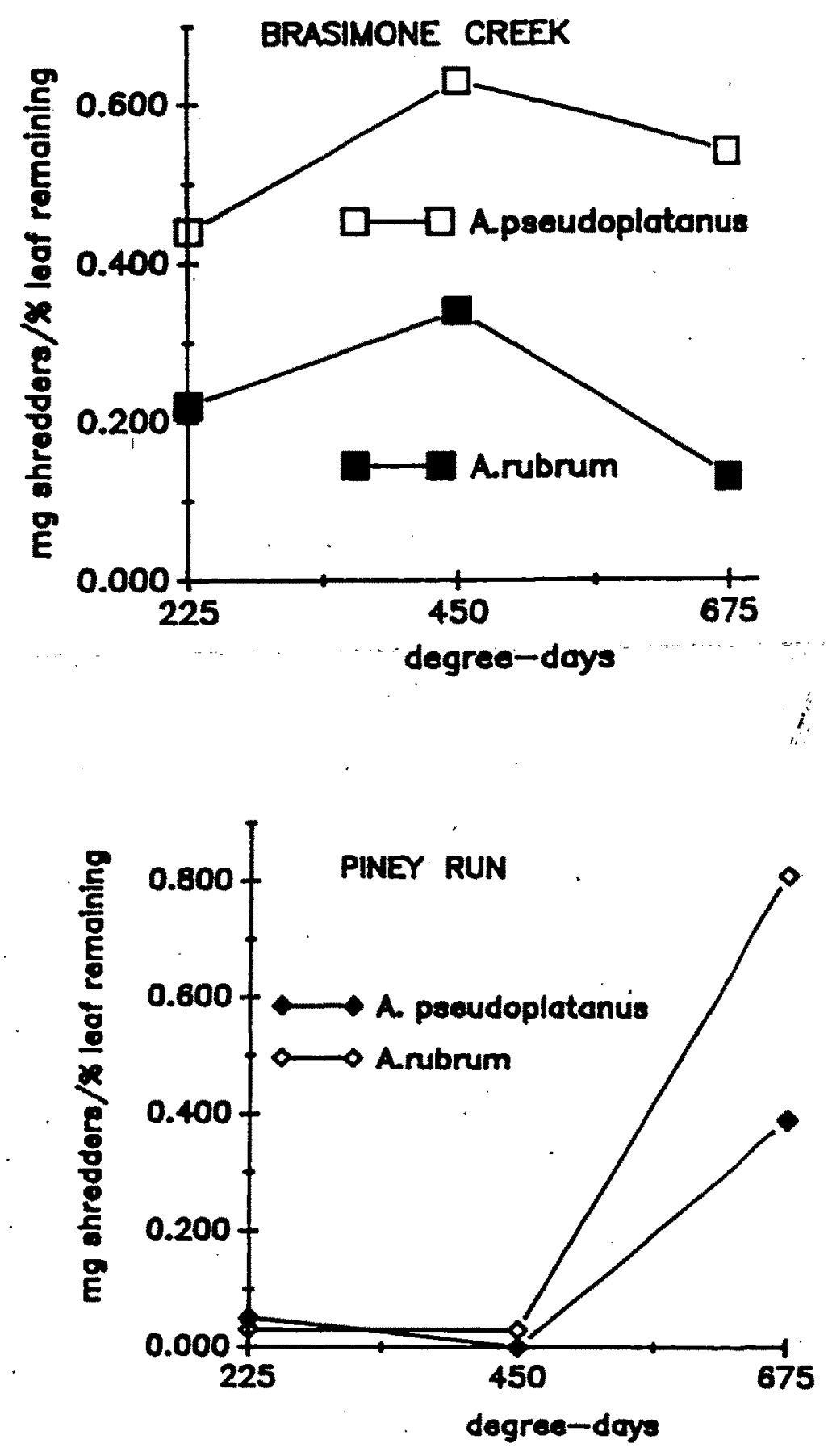

Fig. 5. Mean shredder biomass (expressed per percent leaf mass remaining) over the sampling period. Comparisons in the same genus. Fig. 5. Biomasse moyenne des décomposeurs (exprimée en pourcent du poids de feuille restant) pendant la période de récolte. Comparaisons pour un même genre. 



Fig. 6. Mean shredder biomass (expressed per percent leaf mass remaining) over the sampling period. Comparisons within species. Fig. 6. Biomasse moyenne des décomposeurs (exprimée en pourcent du poids de feuille restant) pendant la période de récolte. Comparaisons pour une même espèce.

\section{Discussion}

In general, leaves of all four species decomposed faster in the Italian stream. Within the same leaf genus, Italian species were processed faster than their American counterparts in both Brasimone Creek and Piney Run.

Despite the differences in the processing rates between the Italian and American streams, breakdown rates followed the same rank ordering within each stream : Acer pseudoplatanus $>$ Ulmus minor $>$ Ulmus americana $>$ Acer rubrum. Such natural ordering of species-specific decomposition rates has been found by other authors as well (Webster \& Waide 1982, Meyer \& Johnson 1983, Benfield \& Webster 1985). Different processing rates of various leaf species that enter woodland streams extend the availability of terrestrial detritus for stream fauna 
through a sequential availability of appropriately conditioned food resources (e.g. Petersen \& Cummins 1974, Cummins et al.1989).

According to the literature (Petersen \& Cummins 1974, Webster \& Benfield 1986), North American elm and maple leaves are normally processed at a fast and medium rate respectively. In the present study both genera were decomposed at a fast rate. Other studies have reported breakdown rates in streams using the leaf-pack technique $: \mathrm{k}=0.0062$ day -1 for Acer rubrum (Petersen \& Cummins 1974), and $\mathrm{k}=0.0061 \mathrm{day}-1$ for Ulmus americana (Gurtz et al. 1982). Mathews and Kowalczewski (1969) estimated a k value of 0.011 day -1 for Acer pseudoplatanus. The most likely explanation for the higher processing rates determined in the present study is temperature difference. Processing rates have been shown to increase with temperature (e.g. Hanson et al. 1984). The other studies reported were conducted in winter, while ours were carried out in the summer months. Difference in processing rates between seasons has been shown by a number of investigators (e.g. Suberkropp et al. 1975, Petersen \& Cummins 1974, Anderson \& Sedell 1979) and related to life cycle of shredders (e.g. Cummins et al. 1989).

The difference in temperature normalized processing rates observed between the Italian and the American stream indicates the influence of the study site such as different microbial and shredder populations. By contrast, the existence of the same sequence in breakdown rates in both the Italian and the American stream indicates the role that chemical and physical characteristics of vegetal tissue play in the process. Thus leaf decomposition in aquatic environments depends upon both intrinsic leaf properties and environmental variables (Melin 1930).

According to the results of this study, leaf genus is not a good predictor of breakdown rate on a holarctic basis. For instance, in Brasimone Creek Acer pseudoplatanus leaves were decomposed three times faster than Acer rubrum. Because temperature was fairly constant during the course of these experiments in both streams, addition of temperature to the one independent variable model was statistically significant in only two cases. Nevertheless, normalizing for temperature basis allowed us to make comparisons between the two streams and would provide a more useful basis by which to compare studies conducted at different seasons.

The role that the shredder functional feeding group plays in detritus processing is indicated by a comparison within leaf species between the Italian and the American streams. Shredder biomass was always significantly higher on the leaves retrieved from Brasimone Creek where leaves lost weight more rapidly. The shredders found on the leaves collected from Brasimone Creek were in general smaller, but much more numerous, than their American counterparts. Although large shredders can remove large pieces of leaf tissue, smaller individuals, by shredding leaf cuticle, can play a significant role in decomposing leaves as well (Wallace et al. 1970).

The results of the comparisons between leaf species showed only a poor correlation between shredder biomass or density and leaf breakdown rate. In Brasimone Creek both shredder density and biomass were significantly higher on the Italian maple in one occasion only (675 degree-days) although this species was processed significantly faster than its North American counterpart. In Piney Run both the Italian elm and maple were processed significantly faster than the North American species, but shredder biomass was never significantly higher on the Italian leaf species. Only shredder density was significantly higher on the Italian maple than on the American maple. The lack of a better correlation could be explained with three hypotheses. Shredders, as well as other macroinvertebrates, are known to colonize leaf accumulations as habitat as well as a food resource (Benfield et al. 1977, Short \& Ward 1980). Consequently higher shredder density does not necessarily mean higher consumption rates. A second explanation is that feeding occurred at a greater rate on the higher quality leaves. Wallace et al. (1970), found that the stonefly Peltoperla maria had the following food preference : dogwood $>$ red maple > white oak, and Golladay et al. (1983) reported the same leaf preference for the stonefly species Pteronarcus proteus. Several authors (Barlocher \& Kendrick 1973a, 1973b, Suberkropp et al. 1983, Arsuffi \& Suberkropp 1984) have reported that some macroinvertebrates consume leaves at rates dependent upon the grade of conditioning of the vegetal tissue. Feeding preference, supposedly related to leaf palatability, were also found for Gammarus pseudolimneous (Barlocher \& Kendrick 1973a, 1973b), and for three species of Trichoptera 
(Arsuffi \& Suberkropp 1984). We propose that shredder macroinvertebrates fed more rapidly on the Italian leaf species because they reached the conditioned stage earlier, and thus became palatable, before the American species.

Finally, Cummins et al. (1989) proposed that shredder biomass in a given stream will be maximized at the time of greatest availability of a litter in a given processing class in a state of conditioning that can support maximal growth. The maximal ratio of shredder biomass per unit weight of leaf remaining, in all three litter-processing categories, occurs when leaf-packs have approximately lost $50 \%$ of their initial weight after leaching (Cummins et Klug 1979). For fast leaf species, the $50 \%$ leaf processing would occur after approximately 300 degree-days. In Brasimone Creek (Fig. 1) all four leaf species lost $50 \%$ of their initial weight (after leaching) after about 300 degree-days, with the exception of Acer rubrum which at that sampling interval had lost only $30 \%$ of its initial weight. In Piney Run (Fig. 1) Ulmus minor and Acer pseudoplatanus lost $50 \%$ of their initial weight after 300 and 350 degree-days respectively. Acer rubrum approached the $50 \%$ weight loss at about 700 degree-days while Ulmus americana never reached this processing point. In Piney Run the fall-winter shredder population is not expected to be well represented until late October, and the springsummer shredder population is expected to have completed their feeding and growing by mid to late August (Cummins et al. 1989), period previous to the beginning of our experiment. In Brasimone Creek, because of its higher elevation, the spring-summer shredder population might behave differently and might have been still abundant, feeding and growing, during the period of our study.

In both streams there was a general increase in total macroinvertebrate biomass throughout the processing period. This was likely related to the initial conditioning period during which leaves are being decomposed by fungi and bacteria but are not yet palatable for macroinvertebrates (e.g: Kaushik \& Hynes 1971, Iversen 1973, Golladay et al. 1983).

The collector functional feeding group was well represented in all leaf-packs. Leaf accumulations filter from upstream and generate from within, FPOM upon which collectors feed (Short et al. 1980).

In general, higher macroinvertebrate density was found on the leaf-incubated placed in Brasimone
Creek. Qualitative observations indicated that the standing crop of CPOM was higher in Brasimone Creek than in Piney Run. This suggests that the leafpacks placed in the Italian stream represented islands of food and habitat for macroinvertebrates whereas in Piney Run, because of the natural abundance of CPOM, macroinvertebrates showed less tendency to colonize new leaves. Webster \& Waide (1982), and Benfield \& Webster (1985), offered a similar explanation for differences they observed in leaf colonization by macroinvertebrates.

The results support the notion that shredders do not specialize on litter of a given plant species as a food source, but rather on appropriately conditioned leaf litter of any species. This was indicated by the fact that native leaves were not processed at a faster rate in their corresponding streams. This importance of conditioning of plant species has been found in other comparisons of processing rates between native and exotic leaf species processing rates (e.g. Pidgeon \& Cairns 1981, Cummins et al. 1989).

\section{Acknowledgments}

We thank Donna M. Gates and Bruna Gumiero for assisting with the field work.

\section{References}

Anderson N.H. \& Cummins K.W. 1978. - Influences of diet on the life histories of aquatic insects. J. Fish. Res. Can., $36: 335-342$.

Anderson N.H. \& Sedell J.R. 1979. - Detritus processing by macroinvertebrates in stream ecosystem. Ann. Rev. Entomol., $24: 351-377$.

Arsuffi T.L. \& Suberkropp K. 1984. - Leaf processing capabilities of aquatic hyphomycetes : interspecific differences and influence on shredder feeding preference. Oikos, 42 : 144-154.

Barlocher F. \& Kendrick B. 1973a. - Fungi and food preferences of Gammarus pseudolimnoeus. Arch. Hydrobiol., 72 : 501-516.

Barlocher F. \& Kendrick B. 1973b. - Fungi and diet of Gammarus pseudolimnoeus (Amphipoda). Oikos, 24 : 295-300.

Benfield E.F., Jones D.R. \& Patterson M.F. 1977. - Leaf-pack processing in a pastureland stream. Oikos, $29: 99-103$.

Benfield E.F. \& Webster J.R. 1985. - Shredders abundance and leaf breakdown in an Appalachian Mountain stream. Freshwat. Biol., 15 ; 113-120.

Boling R.H. Jr., Goodman E.D., Van Sickle J.A., Zimmer J.O., Cummins K.W., Petersen R.C. \& Reice S.R. 1975. - Toward a model of detritus processing in a woodland stream. Eco$\log y, 56: 141-151$.

Brock T.C.M., Boon J.J. \& Paffen B.G.P. 1985. - The effects of season and the water chemistry on the decomposition of Nymphaea alba L. ; weight loss pyrolysis spectrometry of the particulate matter. Aquat. Bot., 21 : 197-229. 
Carpenter S.R. \& Adams M.S. 1979: - Effects of nutrients and temperature on decomposition of Myriophyllum spicatum L. in a hardwater eutrophic lake. Limnol. Oceanogr., 24 : 520-528.

Cummins K.W. 1973. - Trophic relations of aquatic insects. Ann. Rev. Entomol., 18 : 183-206.

Cummins K.W. 1974. - Structure and function of stream ecocystems. BioScience, $24: 631-641$.

Cummins K.W. \& Klug M.J. 1979. - Feeding ecology of stream invertebrates. Ann. Rev. Ecol. Syst., $10:$ 147-172.

Cummins K.W. \& Wilzbach M.A. 1985. - Field procedures for analysis of Functional Feeding Groups of Stream Invertebrates. Appalachian Environmental Laboratory, University of Maryland, Frostburg. Cont. No $1611: 18$ p.

Cummins K.W., Wilzbach M.A., Gates D.M., Perry J.B. \& Taliaferro W.B. 1989. - Shredders and Riparian Vegetation. BioScience, 39 (1) : 24-30.

Cushing C.E., McIntire C.D., Cummins K.W., Minshall G.W., Petersen R.C., Sedell J.R. \& Vannote R.L. 1983. - Relationship among chemical, physical, and biological indices along river continua based on multivariate analysis. Arch. Hydrobiol., 93 (3) : 317-326.

Findlay S.E.G. \& Arsuffi T.L. 1989. - Microbial growth and detritus transformations during decomposition of leaf litter in a stream. Freshwat. Ecol., $21: 261-269$.

Fisher S.G. \& Likens G.E. 1973. - Energy flow in Bear Brook, New Hampshire : an integrative approach to stream ecosystem metabolism. Ecol. Monogr., $43:$ 421-439.

Gazzera S., Cummins K.W. \& Salmoiraghi G. 1991 . - A comparison of leaf litter processing in Maryland and Italian streams. Verh. Internat. Verein, Limnol., 24 : 1703-1706.

Golladay S.W., Webster J.R. \& Benfield E.F. 1983. - Factors affecting food utilization by a leaf shredding aquatic insect : leaf species and conditioning time. Holarct. Ecol., 6 : 157-162.

Gurtz M.E., Marzolf G.R., Killingbeck K.T., Smith D.L. \& McAarthur J.V. 1982. - Organic matter loading and processing in a pristine stream draining a tallgrass prairie/riparian forest watershed. Kans. Water Resources Res. Inst. Contrib. 230. Manhattan, Kans.

Hanson B.J., Cummins K.W., Barnes J.R. \& Carter M.W. 1984. - Leaf litter processing in aquatic systems : A two variable model. Hydrobiologia, $111: 21-29$.

Hynes H.B.N. \& Kaushik N.K. 1969. - The relationship between dissolved nutrient salts and protein production in submerged autumnal leaves. Int. Ver. Theor. Angew. Limnol. Verh., $17: 95-103$.

Iversen T.M. 1973. - Decomposition of autumn-shed beech leaves in a spring brook and its significance for the fauna. Arch. Hydrobiol., 72 : 305-312.

Kaushik N.K. \& Hynes H.B.N. 1971. - The fate of dead leaves that fall into streams. Arch. Hydrobiol., $68: 465-515$.

Mathews C.P. \& Kowalczewski A. 1969. - The disappearance of leaf litter and its contribution to production in the River Thamas. J. Ecol., 57 : 543-552.

Melin E. 1930. - Biological decomposition of some types of litter from North America forests. Ecology., 11 : 72-101.

Merritt R.W. \& Cummins K.W. 1984. - An Introduction to the Aquatic Insect of North America. Kendall/Hunt, Dubuque, Iowa, USA : $722 \mathrm{p}$.
Merritt R.W., Cummins C.W. \& Barnes J.R. 1979. - Demonstration of stream watershed community process with some simple bioassay techniques. In V.H. Resh and D.M. Rosemberg, eds, Innovative Teaching in Aquatic Entomology. Con. Spec. Publ. Fish. Aquat. Sci. $43: 1-118$.

Meyer J.L. \& Johnson C. 1983. - The influence of elevated nitrate concentration rate of leaf decomposition in a stream. Freshwat. Biol., 13 : 177-183.

Minshall G.W. 1967. - Role of allochthonous detritus in the trophic structure of a woodland stream. Ecology, 48 : 139-149.

Minshall G.W., Petersen R.C., Cummins K.W., Bott T.L., Sedell J.R., Cushing C.E. \& Vannote R.L. 1983. - Interbiome comparison of stream ecosystem dynamics. Ecol. Monogr., 53 : $1-25$.

Minshall G.W., Cummins K.W., Petersen R.C., Cushing C.E., Bruns D.A., Sedell J.R. \& Vannote R.L. 1985. - Development in stream ecosystem theory. Can. J. Fish. Aquat. Sci., 42 : 1045-1055.

Olson J.S. 1963. - Energy storage and the balance of producers and decomposers in ecological systems. Ecology, 44 : 322-331.

Petersen R.C. 1984. - Detritus decomposition in endogenous and exogenous rivers of a tropical wetland. Verh. Internat. Verein. Limnol., 22 : 1962-1931.

Petersen R.C. \& Cummins K.W. 1974. - Leaf processing in a woodland stream. Freshwat. Biol., 4 : 345-368.

Pidgeon J.W.R. \& Cairns S.C. 1981. - Decomposition and colonization by invertebrates of native and exotic leaf material in a small stream in New England (Australia). Hydrobiologia, $77: 113-127$.

Rogers L.E., Buschbom R.L. \& Waston C.R. 1977. - LengthWeight relationships of shrub-steppe invertebrates. Ann. Entomol. Soc. Am., 70 (1) : 51-53.

Short R.A. \& Ward J.V. 1980. - Leaf litter processing in a regulated Rocky Mountain Stream. Can. J. Fish. Aquatic. Sci., $37:$ 123-127.

Short R.A., Canton S.P. \& Ward J.V. 1980. - Detrital processing and associated macroinvertebrates in a Colorado Mountain Stream. Ecology, $61:$ 727-732.

Smock L.A. 1980. - Relationships between body size and biomass of aquatic insects. Freshwat. Bioli, $10: 375-382$.

Snedecor G.W. \& Cochran W.G. 1980. - Statistical methods. Iowa State University Press. Ames, Iowa : 507 p.

Sokal R.R. \& Roholf F.J. 1981. - Biometry. Second edition. W.H. Freeman, San Francisco, California : 859 p.

Suberkropp K., Klug M.J. \& Cummins K.W. 1975. - Community processing of leaf litter in woodland streams. Verh. Internat. Verein. Limnol., 19 : 1653-1658.

Suberkropp K. \& Klug M.J. 1976. - Fungi and bacteria associated with leaves during processing in a woodland stream. Ecology, 57 : 707-719.

Suberkropp K., Arsuffi T.L. \& Anderson J.P. 1983. - Comparison of degradative ability, enzymatic activity, and palatability of aquatic hyphomycetes grown on leaf litter. Appl. Environ. Microbiol., 46 (1) : 237-244.

Vannote R.L., Minshall G.W., Cummins K.W., Sedell J.R. \& Cushing C.E. 1980. - The River Continuum Concept. Can. J. Fish. Aquat. Sci., 47 : 130-137. 
Wallace J.B., Woodall S.R. \& Sherbergen F.F. 1970. - Breakdown of leaves by feeding of Peltoperla maria nymphs (Plecoptera : Peltoperlidae). Ann. Entomol. Soc. Am., 63 : 573-567.

Wallace J.B., Webster J.R. \& Cuffney T.F. 1982. - Stream detritus dynamics : regulation by invertebrates consumers. Oecologia, $53: 197-200$.

Ward G.M. \& Cummins K.W. 1978. - Life history and growth pattern of Paratendipes albinus in a Michigan hardwater stream. Ann. Entomol. Soc. Am., 71 : 272-284.
Webster J.R. \& Waide J.B. 1982. - Effects of forest clear-cutting on leaf breakdown in a southern Appalachian stream. Freshwat. Biol., $12: 331-344$.

Webster J.R. \& Benfield E.F. 1986. - Vascular plant breakdown in freshwater ecosystems. Ann. Rev. Ecol. Syst., 17 : 567-594.

Wilzbach M.A. \& Cummins K.W. 1989. - An assessment of short-term depletion of stream macroinvertebrate benthos by drift. Hydrobiologia, 185 : 29-39. 